A - preparing concepts

$\mathrm{B}$ - formulating methods

$\mathrm{C}-$ conducting research

$\mathrm{D}$ - processing results

E - interpretation and conclusions

$\mathrm{F}$ - editing the final version

\section{Assessment of the correlations between the level of physical activity and sociodemographic factors, functional capabilities and cognitive capabilities of elderly persons from south-eastern Poland}

\section{Ocena zależności między poziomem aktywności fizycznej a czynnikami socjodemograficznymi, sprawnością funkcjonalną i poznawczą osób starszych mieszkających na terenie południowo-wschodniej Polski}

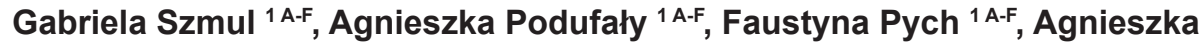

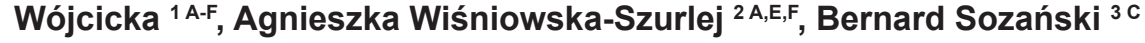 \\ Faculty of Medicine, University of Rzeszow; Wydział Medyczny, \\ Uniwersytet Rzeszowski \\ ${ }^{1}$ Student Research Club - Physiotherapy in Geriatrics and Health Prevention, \\ Institute of Physiotherapy; Studenckie Koło Naukowe Fizjoterapii w Geriatrii \\ i Profilaktyce Zdrowia, Instytut Fizjoterapii \\ ${ }^{2}$ Institute of Physiotherapy; Instytut Fizjoterapii \\ ${ }^{3}$ Scientific and Medical Centre for Innovative Research; Przyrodniczo-Medyczne \\ Centrum Badań Innowacyjnych
}

https://doi.org/10.5114/areh.2018.83389

Abstract

Introduction: Insufficient physical activity constitutes one of the most problematic issues in the contemporary society. Data show that seniors should take up physical activity as it considerably affects their health and quality of life.

Material and method: The study included 76 individuals over 60 years of age who actively participated in social life (Senior Clubs, Country Housewives' Clubs, Folk groups) in south-eastern Poland. The International Physical Activity Questionnaire (IPAQ), Timed Up and Go Test (TUG), Timed Up and Go Cognitive Test (TUG cog), 10-Meter Walk Test (10MWT), right and left handgrip test, Functional Chair Stand Test (FS test), Geriatric Depression Scale (GDS) and Mini Mental State Examination (MMSE) were applied in the study.

Results: It was revealed that male participants $(\mathrm{p}=0.001)$, individuals being in a relationship $(p=0.02)$ and subjects who had never had any fractures before $(p=0.02)$ demonstrated higher levels of physical activity. In the examined group, a higher level of physical activity significantly correlated with a higher level of muscle strength of lower limbs $(p=0.32)$ and left handgrip strength $(p=0.26)$, shorter time of covering the distance of 10 metres $(p=-0.23)$ and a higher level of cognitive capabilities $(p=0.29)$.

email: gabriela.szmul@wp.pl

The research was financed from the authors' own resources

Badania sfinansowane ze środków własnych autorów 


\section{Key words:}

\section{Słowa kluczowe:}

Conclusions: Physical activity depends on sociodemographic factors and correlates with functional and cognitive capabilities of seniors. Therefore, it is important to promote active lifestyle among elderly individuals and to draw attention to its positive influence on everyday functioning.

\section{seniors, physical activity, functional capabilities}

\section{Streszczenie}

Wstęp: Jedną z najbardziej problematycznych kwestii współczesnego społeczeństwa jest brak podejmowania wystarczającej aktywności ruchowej. Z danych wynika, iż seniorzy powinni podejmować aktywność ruchową, gdyż w decydującym stopniu wpływa ona na ich zdrowie oraz jakość życia.

Materiał $i$ metody: Badaniem objęto grupę 76 osób w wieku powyżej 60 roku życia, biorących aktywny udział w życiu społecznym (Kluby Seniora, Koła Gospodyń Wiejskich, Zespoły ludowe) mieszkających na terenie Polski południowo-wschodniej. Celem przeprowadzenia badania wykorzystano Międzynarodowy Kwestionariusz Aktywności Fizycznej (IPAQ), Timed Up and Go Test (TUG) oraz Timed Up and Go Test poznawczy (TUG cog), 10-metrowy test chodu (10MWT), test siły uścisku prawej i lewej ręki, czynnościowy test wstawania z krzesła (FS Test), Geriatryczną Skalę Oceny Depresji (GDS), Krótką Skalę Oceny Stanu Psychicznego (MMSE).

Wyniki: Wykazano, że kobiety $(\mathrm{p}=0,001)$, osoby będące w związku $(\mathrm{p}=0,02)$ oraz te, $\mathrm{u}$ których nie wystąpiły wcześniej złamania $(\mathrm{p}=0,02)$ charakteryzowały się istotnie większym stopniem aktywności fizycznej. W badanej grupie wyższy poziom aktywności ruchowej jest istotnie związany z wyższym poziomem siły mięśniowej kończyn dolnych $(\mathrm{p}=0,32)$ i uścisku lewej ręki $(\mathrm{p}=0,26)$, skróceniem czasu pokonania dystansu 10 metrów $(\mathrm{p}=-0,23)$ oraz wyższym poziomem sprawności poznawczej $(\mathrm{p}=0,29)$.

Wnioski: Aktywność fizyczna wpływa na sprawność funkcjonalną i poznawczą seniorów. Z tego względu ważne jest promowanie aktywnego stylu życia wśród osób starszych i zwrócenie uwagi na jego pozytywny wpływ na codzienne funkcjonowanie.

seniorzy, aktywność ruchowa, sprawność czynnościowa

\section{Introduction}

Normal aging, which is accompanied by insidious progressive changes, is a natural, irreversible and long-lasting process which affects every human $[1,2]$. The aging process begins at the age of 2025 [2], while according to the World Health Organization (WHO), the age of 60 marks the beginning of old age [1]. Currently, life expectancy is increasing [3]. This increase is caused, among other things, by improvements in quality of life [4] and the advancements in medicine [3].

In 2017, the inhabitants of the European Union aged 65 or more constituted $19 \%$ of the population, while it is estimated that the percentage of individuals aged 80 or more will have doubled and reached the level of $13 \%$ of the population by 2080 [5]. In Poland in 2017, the number of inhabitants aged 65 or more increased by 217000 and reached 6.5 million, which constitute $17 \%$ of the general population [6]. Recent data show that there is a $50 \%$ chance that by 2030 , life expectancy among women will exceed 90 years of age, which seemed unattainable at the turn of the $20^{\text {th }}$ century [7].

The development of chronic diseases which often occur with aging may limit the functioning of the elderly. The more chronic diseases are diagnosed in a particular person, the higher the disability level [8]. Health status deterioration, which results in disability, leads to the elderly individuals' early inability to work and loss of independence [9]. People with decreased psychophysical capabilities are also less likely to participate in social life [2]. Gębska et al. demonstrated that the life of elderly individuals is highly dependent on the surroundings in which they live. These researchers concluded that elderly people who actively participate in social activities demonstrated an improved psychophysical state [10]

Currently there is a growing interest in the correlation between physical activity and the health 
status of elderly individuals [11]. Regardless of age, insufficient physical activity constitutes one of the most problematic issues of contemporary society [12]. It is estimated that worldwide, approximately 3.2 million people a year die because of the lack of adequate physical activity [13]. In many populations, it is physical activity that is one of the most influential positive health indicators [14]. Therefore, elderly individuals should engage in physical activity, since it directly affects their health and quality of life. It is well understood that physical activity positively influences mental processes, which reduces the occurrence of depression and anxiety [15].

According to WHO recommendations, individuals over 65 should engage in moderate aerobic physical activity for at least 150 minutes a week or high-intensity physical activity for at least 75 minutes a week [16]. However, as data published in 2018 show, as many as $71 \%$ of the individuals over 55 from the European Union did not perform the recommended high-intensity physical activity, while $56 \%$ did not perform moderate physical activity [17].

This study sought to assess the correlations between the level of physical activity and sociodemographic factors, functional capabilities and cognitive capabilities of elderly persons from south-eastern Poland.

\section{Material and method}

The study included 76 individuals aged over 60 who actively participated in social life (Senior Clubs, Country Housewives' Clubs, Folk groups) in south-eastern Poland. The study inclusion criteria were as follows: aged over 60 years, written informed consent to participate in the study, club membership, no depression (0-5 points in GDS) or moderate depression (6-10 in GDS), no cognitive impairment (27-30 points in MMSE), cognitive impairment without dementia (24-26 points in MMSE) or mild cognitive impairment (19-23 points in MMSE). The exclusion criteria were as follows: serious systemic diseases.

Participants signed a written consent to participate in the study and received information regarding its aims and protocols. The Bioethical Commission of the University of Rzeszow approved the study design.
The research was carried out from March 2017 to April 2018. Data was gathered within one day in a specially prepared room. In order to assess physical activity, psychophysical state and cognitive capabilities, the following tests and clinical scales were used:

- International Physical Activity Questionnaire (IPAQ): the short version includes 7 questions regarding different intensity levels of physical activity. On the basis of the obtained results, the study participant was assigned to one of the following activity levels: high (at least 1500 MET minutes a week), moderate (600-1500 MET minutes a week), low (below 600 MET minutes a week) $[14,18]$.

- Tinetti POMA test: used to assess balance and risk of falls. The following scoring rules were applied: 26-28 points - no risk of falls, $19-25$ points moderate risk of falls, $\leq 18$ points -5 times higher risk of falls compared to individuals with a positive result [19].

- Timed Up and Go Test (TUG) and the modified Timed Up and Go Cognitive Test version (TUG $\operatorname{cog}$ ): were used to assess balance and risk of falls. The following scoring rules were applied: a score above 13.5 seconds in the TUG and above 15 seconds in the TUG cog indicated an increased risk of falls [20,21].

- 10-Meter Walk Test (10MWT): was used to assess walking speed. The study participants' task was to walk for 10 meters in the shortest time possible. The result was measured in seconds [22].

- Handgrip strength test: assessed with a Jamar hand dynamometer. According to the procedure, the study participants were asked to maintain a maximal-strength grip for 6 seconds. The participants were sitting in the following position: feet supported on the floor, arms unsupported held close to the trunk, elbow bent at 90 degrees, forearm in an intermediate position, wrist between 0 and 30 degrees. The test was performed 3 times for each hand with an interval to avoid fatigue. The result (mean from the three measurements) was presented in kilograms [23].

- Functional Chair Stand Test (FS Test): was used to determine muscle strength of lower limbs. In this test, the participant was asked to perform the highest possible number of complete stands from a sitting position within 30 seconds. One trial was registered [24]. 
- 15-point Geriatric Depression Scale (GDS): was used to obtain subjective assessment of the senior participants' satisfaction with their quality of life as well as their mood and happiness. The result above 5 points indicated mild depression. In turn, the result above 10 points meant the presence of severe depression $[25,26]$.

- Mini Mental State Examination (MMSE): was to assess cognitive functions. The results were interpreted in the following manner: 27-30 points - no cognitive impairment, $24-26$ points - mild cognitive impairment, 19-23 points - moderate cognitive impairment, 11-18 points - average cognitive impairment, $0-10$ points - severe impairment [27].

\section{Statistical analysis}

Statistical analyses were performed using, Statistica software version 13.1. Arithmetic means and standard deviations were calculated to describe the distribution of numerical values. Pearson correlation coefficient was applied in order to determine the level of linear correlation between random data. The following scale regarding the strength of the correlation for $|\mathrm{r}|$ was adopted:

$<0.2-$ no linear correlation

$0.2-0.4$ - weak correlation

0.4-0.7 - moderate correlation

$0.7-0.9$ - quite strong correlation

$>0.9$ - very strong correlation.

Moreover, Mann-Whitney test, whose aim is to compare two independent groups, was applied. The level of statistical significance was set at $\mathrm{p}<0.05$.

\section{Results}

The study was conducted on a group of elderly individuals aged 60 to 89 , including 56 women (73.7\%) and 20 men (26.3\%). Mean age of the study participants was $71.4 \pm 7.3$. Characteristics of the examined individuals and their functional and cognitive capabilities are presented in tables 1 and 2 .
Tab. 1. Characteristics of the study participants

\begin{tabular}{|c|c|}
\hline Variable & Study group \\
\hline $\begin{array}{l}\text { Sex [\%] } \\
\text { Women } \\
\text { Men }\end{array}$ & $\begin{array}{l}73.7 \\
26.3\end{array}$ \\
\hline Age in years $[ \pm \mathrm{SD}]$ & $71.4 \pm 7.3$ \\
\hline Body height in $\mathrm{cm}[ \pm \mathrm{SD}]$ & $162.1 \pm 6.7$ \\
\hline Body mass in $\mathrm{kg}[ \pm \mathrm{SD}]$ & $79.1 \pm 14.1$ \\
\hline $\begin{array}{l}\text { Marital status [\%] } \\
\text { Single } \\
\text { In a relationship }\end{array}$ & $\begin{array}{l}50 \\
50\end{array}$ \\
\hline $\begin{array}{l}\text { Education [\%] } \\
\text { Primary/vocational } \\
\text { At least secondary }\end{array}$ & $\begin{array}{l}67.1 \\
32.9 \\
\end{array}$ \\
\hline $\begin{array}{l}\text { The number of falls within the last } \\
12 \text { months [\%] } \\
\text { None } \\
\text { At least one }\end{array}$ & $\begin{array}{l}71.1 \\
28.9\end{array}$ \\
\hline $\begin{array}{l}\text { Number of fractures [\%] } \\
\text { None } \\
\text { At least one }\end{array}$ & $\begin{array}{l}77.6 \\
22.4 \\
\end{array}$ \\
\hline
\end{tabular}

Tab. 2. Characteristics of functional and cognitive capabilities of the study participants

\begin{tabular}{|l|c|}
\hline \multicolumn{1}{|c|}{ Clinical scales and tests } & Study group \\
\hline IPAQ (mean MET) [ \pm SD] & $4816.7 \pm 4466.8$ \\
At least moderate [\%] & 77.6 \\
Low [\%] & 22.7 \\
\hline Tinetti POMA Test [ \pm SD] & $26.5 \pm 3$ \\
High risk of falls [\%] & 2.6 \\
Moderate risk of falls [\%] & 17.1 \\
No risk of falls [\%] & 80.3 \\
\hline TUG [ \pm SD] & $10.3 \pm 3.1$ \\
Increased risk of falls [\%] & 17.1 \\
No risk of falls [\%] & 82.9 \\
\hline TUG cog [ \pm SD] & $14.06 \pm 5.2$ \\
Increased risk of falls [\%] & 40.8 \\
No risk of falls [\%] & 59.2 \\
\hline 10 MWT [ \pm SD] & $9.75 \pm 2.9$ \\
\hline Right handgrip strength [ \pm SD] & $30 \pm 34.5$ \\
\hline Left handgrip strength [ \pm SD] & $23 \pm 10$ \\
\hline FS Test [ \pm SD] & $12.2 \pm 3.1$ \\
\hline GDS [ \pm SD] & $3.5 \pm 3$ \\
No depression [\%] & 76.3 \\
Increasing depression [\%] & 23.7 \\
\hline MMSE [ \pm SD] & $26 \pm 3.3$ \\
Moderate cognitive impairment [\%] & 18.4 \\
Mild cognitive impairment [\%] & 35.5 \\
No cognitive impairment [\%] & 46.1 \\
\hline
\end{tabular}

Considering physical activity, statistically significant differences (marked in red) were revealed between three variables; gender, marital status and the number of fractures (Tab. 3). Men demonstrated significantly higher levels of physical activity than women $(\mathrm{p}=0.001)$. Also, individuals who reported that they were in a relationship had a higher level of physical activity than single individuals $(\mathrm{p}=0.02)$. Considering the number of fractures experienced 
by the elderly participants, it was noted that their lack meant a higher level of physical activity, while having fractures in the past correlated with reduced levels of physical activity $(\mathrm{p}=0.02)$.

Tab. 3. Comparison of the results of mean physical activity in two independent groups

\begin{tabular}{|c|c|c|}
\hline Variable & $\begin{array}{c}\text { IPAQ }(\text { MET) } \\
\text { Mean }[ \pm \text { SD] }]\end{array}$ & p \\
\hline Sex & $3658.2[ \pm 2922.8]$ & \\
Women & $8060.3[ \pm 6244.8]$ & 0.001 \\
Men & $3900.2[ \pm 4314.8]$ & \\
\hline $\begin{array}{c}\text { Marital status } \\
\text { Single } \\
\text { In a relationship }\end{array}$ & $5733.2[ \pm 4483.4]$ & 0.02 \\
\hline $\begin{array}{c}\text { Education } \\
\text { Primary/vocational } \\
\text { At least secondary }\end{array}$ & $4929.2[ \pm 4935.4]$ & \\
\hline $\begin{array}{c}\text { Number of falls within } \\
\text { the last 12 months } \\
\text { None }\end{array}$ & $4587.1[ \pm 3394.4]$ & 0.70 \\
At least one & $4549.5[ \pm 3821]$ & \\
\hline Number of fractures & $5472.6[ \pm 5811.7]$ & 0.98 \\
None & $5140.8[ \pm 4116.3]$ & \\
At least one & $3691.9[ \pm 5510.9]$ & 0.02 \\
\hline
\end{tabular}

The data demonstrated that physical activity correlated with psychophysical and cognitive capabilities of elderly individuals (Table 4). A correlation was found between the result obtained in the IPAQ and 10MWT, FS Test, left handgrip test and MMSE scale. It was noted that the higher the level of physical activity, the shorter the time needed to cover the distance of 10 meters $(|\mathrm{r}|=-0.23)$, the greater the muscle strength of lower limbs and left handgrip $(|\mathrm{r}|=0.32$ and 0.26 , respectively) and the smaller the impairments in the cognitive sphere $(|r|=0.29)$.

Tab. 4. Correlations between physical activity and general state of the study participants

\begin{tabular}{|c|c|}
\hline Variable & $\begin{array}{c}\text { IPAQ (the sum of MET) } \\
|\mathbf{r}|\end{array}$ \\
\hline Age & -0.11 \\
\hline BMI & -0.14 \\
\hline Tinetti POMA Test & 0.18 \\
\hline TUG & -0.06 \\
\hline TUG cog & 0.01 \\
\hline 10MWT & -0.23 \\
\hline Right handgrip test & 0.11 \\
\hline Left handgrip test & 0.26 \\
\hline FS Test & 0.32 \\
\hline GDS & -0.17 \\
\hline MMSE & 0.29 \\
\hline
\end{tabular}

\section{Discussion}

Typically the level of physical activity decreases with age, which is often related to losses of functional capabilities [28]. As a result of economic and social changes which occur in the world, the so-called sedentary lifestyle is becoming a common phenomenon. It leads to numerous disorders and diseases. Currently, physical activity itself is also the subject of research by health psychologists [29]. Regular physical activity is indispensable in the process of healthy ageing, since it helps to reduce functional limitations and disabilities among elderly individuals [30].

In our research, it was observed that $77.6 \%$ of the of the participants engaged in at least moderate levels of physical activity. In the study group, men demonstrated significantly higher levels of physical activity than women $(\mathrm{p}=0.001)$. Skotnicka and Pieszko, who examined 105 women and 93 men over 80 years of age, also reported that men had higher levels of physical activity [31]. Daniel Puciato et al. examined 2053 individuals (987 women and 1066 men) aged 30 to 65 . In this study group, it was also men who followed the recommendations regarding physical activity to a larger extent [32]. In turn, the research by Krzepota et al. revealed different results. The authors examined 72 individuals (14 men and 58 women) who were students of the University of the Third Age. A high or moderate level of physical activity was noted in $59.3 \%$ of the study participants. However, the researchers did not find statistically significant differences between men and women [18].

This study showed that individuals being in a relationship as well as those who did not experience any bone fractures demonstrated significantly higher levels of physical activity than single persons and seniors who had fractures in the past $(p=0.02)$. In addition, no statistically significant correlation was found between the level of education and the level of physical activity. This was not the case in a study by Puciato et al. where a correlation between physical activity and education was observed. These researchers aimed to determine the correlations between physical activity and socio-economic or professional factors among adults from Katowice. The researchers noted that the lower the level of education, the higher the level of physical activity [32]. Such a correlation may stem from the fact that individuals with a higher level of education are more engaged in leisure time physical activity, while 
persons with a lower level of education are usually more physically active in their work [33].

In the study group, persons demonstrating higher levels of physical activity had stronger lower limbs and were able to perform more repetitions of chair stand in 30 seconds $(|\mathrm{r}|=0.32)$. In their research on 1288 individuals over 60 years of age, Milanović et al. also revealed a correlation between physical activity and chair stand test $(\mathrm{p}<0.001)$ [28].

Our own research with the use of a dynamometer revealed that together with an increase in the level of physical activity, left handgrip strength also grew $(|r|=0.26)$. According to Hwang et al., a higher level of physical activity correlated significantly with a lower risk of weak grip of a dominating hand after the age of 65 [34].

A significant correlation was also noted in the case of 10MWT. A shorter time of walking this distance correlated with higher physical activity. The above correlation, considering the aforementioned parameters, has not been examined in elderly individuals so far. Therefore, it is not possible to compare our findings with the results of other authors.

Our study revealed that worse results obtained in MMSE correlated with a lower level of physical activity. The research confirmed that performing regular physical activity exerted a significant influence on cognitive capabilities of elderly individuals. Similar results were obtained by Albuquerquea et al., who examined a group of 149 elderly people and noted that low physical activity correlated with the occurrence of cognitive impairments among elderly individuals, which considerably affected their quality of life [35].
Both in our own study and in the study by Pet-Ming Leung et al., no correlations between decreased physical activity and increased depression were noted [36]. Different results were obtained by Reichert et al., who proved that a higher level of physical activity correlated with a lower frequency of occurrence of depression symptoms. The analysis that considered the division into groups according to sex revealed that this correlation was noted only in the group of men. Simultaneously, it was indicated that men who were very active were less prone (by as much as $68 \%$ ) to depression compared to the group of men who were insufficiently active [37].

A relatively low number of study participants was a limitation of our study. Moreover, in order to diversify the group, the study should be extended to the whole area of Poland.

\section{Conclusions}

The research confirmed that there exists a correlation between physical activity and sociodemographic factors, psychophysical capacity and cognitive capabilities of seniors actively participating in social life. A higher level of physical activity correlated significantly with a higher level of lower limb muscle strength and left handgrip strength, shorter time of walking the distance of 10 meters and a higher level of cognitive capabilities. Therefore, it is important to promote an active lifestyle among elderly individuals and draw attention to its positive influence on everyday life.

\section{References}

1. Skubal A, Sudoł I, Ciąpała G, Ćwirlej-Sozańska A, Wiśniowska-Szurlej A, Wilmowska-Pietruszyńska A. Ocena sprawności funkcjonalnej i ryzyka upadków osób starszych z otępieniem lekkiego i średniego stopnia. Med Rev. 2016;14(4): 427-38.

2. Kaźmierczak U, Radzimińska A, Dzierżanowski M, Bułatowicz I, Strojek K, Srokowski G, et al. Korzyści z podejmowania regularnej aktywności fizycznej przez osoby starsze. J Educ Health Sport. 2015;5(1):56-68.

3. Ćwirlej-Sozańska A, Wilmowska-Pietruszyńska A, Wiśniowska A, Guzik A, Drużbicki M, Sozański B. Ocena mobilności, równowagi ciała oraz ryzyka złamania u osób starszych. Med Rew. 2016;14(2):134-47.

4. Tavares LR, Barbosa MR. Efficacy of group psychotherapy for geriatric depression: A systematic review. Arch Gerontol Geriat. 2018;78:71-80.

5. Eurostat Statistics Explained [Internet]. Population structure and ageing; c2018 [cited 2018 Aug 13]. Available from: http:// ec.europa.eu/eurostat/statistics-explained/index.php/Population_structure_and_ageing.

6. Statistics Poland [Internet]. Warsaw; c1995-2018 [cited 2018 Aug 13] Demographic situation in Poland up to 2017. Births and fertility; [about 3 screens] Available from: http://stat.gov.pl/en/topics/population/population/demographic-situation-in-poland-up-to-2017-births-and-fertility,8,1.html.

7. Kontis V, Bennett JE, Mathers CD, Li G, Foreman K, Ezzati M. Future life expectancy in 35 industrialised countries: projections with a Bayesian model ensemble. Lancet. 2017;389(10076):1323-35. 
8. Ćwirlej-Sozańska A, Wilmowska-Pietruszyńska A, Sozański B, Wiśniowska-Szurlej A. Analysis of Chronic Illnesses and Disability in a Community-Based Sample of Elderly People in South-Eastern Poland. Med Sci Monit. 2018;24:1387-96.

9. Ćwirlej-Sozańska A, Wilmowska-Pietruszyńska A. Assessment of health, functioning and disability of a population aged 60-70 in south-eastern Poland using the WHO Disability Assessment Schedule (WHODAS 2.0). Ann Agr Env Med. 2018;25(1): 124-30.

10. Gębska M, Weber-Nowakowska K, Wojciechowska A, Zawarska M, Czajka N, Szafiarz A, et al. Odmienne środowiska egzystencji życiowej jako czynnik różnicujący funkcje poznawcze i czynności dnia codziennego w grupie osób powyżej 50. roku życia. Rocz PAM. 2014;60,1:93-6.

11. Eckert KG, Lange MA. Comparison of physical activity questionnaires for the elderly with the International Classification of Functioning, Disability and Health (ICF) - an analysis of content. BMC Public Health. 2015;15:249-60.

12. Biernat E. Międzynarodowy Kwestionariusz Aktywności Fizycznej - polska długa wersja. Med Sport. 2013;1(4):1-15.

13. World Health Organization [Internet] Global status report on noncommunicable diseases 2014 [updated 2014]. Available from: http://apps.who.int/iris/bitstream/handle/10665/148114/9789241564854_eng.pdf?sequence=1.

14. Biernat E, Stupnicki R, Gajewski AK. Międzynarodowy Kwestionariusz Aktywności Fizycznej (IPAQ) - wersja polska. Wych Fiz Sport. 2007;51(1):47-54.

15. Grzegorczyk J, Kwolek A, Wolan A, Bazarnik K. Ocena stanu emocjonalnego aktywnych seniorów. Prz Med Uniw Rzesz. 2008;1:27-33.

16. World Health Organization [Internet] Global Recommendations on Physical Activity for Health: 65 years and above [updated 2011]. Available from: http://www.who.int/dietphysicalactivity/physical-activity-recommendations-65years.pdf.

17. Ministerstwo Sportu i Turystyki Rzeczypospolitej Polskiej [Internet]. Warszawa; c2018 [cited 2018 Aug 21] Eurobarometr 472: Sport i aktywność fizyczna 2017; [about 4 screens] Available from: https://www.msit.gov.pl/pl/sport/badania-i-analizy/ aktywnosc-fizyczna-spol/575,Aktywnosc-fizyczna-spoleczenstwa.html.

18. Krzepota J, Biernat E, Florkowicz B. Poziom aktywności fizycznej słuchaczy Uniwersytetu Trzeciego Wieku o zróżnicowanym indeksie masy ciała. Med Og Nauk Zdr. 2013;19(2):200-5.

19. Kamińska MS, Brodowski J. Ocena zagrożenia niedożywieniem pacjentów w wieku podeszłym objętych podstawową opieką zdrowotną w kontekście ryzyka upadku. Med Og Nauk Zdr. 2013;19(4):544-48.

20. Lewko J, Kamińska KM, Doroszkiewicz H, Talarska D, Sierakowska M, Krajewska-Kulak E. Ocena narażenia na upadki a wydolność funkcjonalna wśród osób starszych w środowisku zamieszkania. Probl Pielęg. 2014;22(2):159-64.

21. Shumway-Cook A, Brauer S, Woollacott M. Predicting the Probability for Falls in Community-Dwelling Older Adults Using the Timed Up \& Go Test. Phys Ther. 2000;80:896-903.

22. Novaes RD, Miranda AS, Dourado VZ. Usual gait speed assessment in middle-aged and elderly Brazilian subjects. Rev Bras Fisioter. 2011;15:117-22.

23. Zasadzka E, Strzesak D, Poterska A, Trzmiel T, Pawlaczyk M. Siła uścisku ręki u osób po 65 roku życia. Geriatria. 2017;11:117-22.

24. Mętel S, Kwiatkowska A, Głodzik J, Szczygieł E. Wykorzystanie testu Functional Strength w ocenie stanu funkcjonalnego oraz w monitorowaniu procesu rehabilitacji medycznej osób starszych. Gerontol Pol. 2012;20,4:148-54.

25. Szczepańska J, Greń G, Woźniewski M. Zaburzenia nastroju - istotny czynnik w procesie fizjoterapii osób w podeszłym wieku. Fizjoter Pol. 2008;2(4):170-8.

26. Kowalska J, Szczepańska-Gieracha J, Piątek J. Zaburzenia poznawcze i emocjonalne a długość pobytu osób starszych w Zakładzie Opiekuńczo-Leczniczym o Profilu Rehabilitacyjnym. Pszchogeraitr Pol. 2010;7(2):61-70.

27. Bujnowska-Fedak MM, Grata-Borkowska U, Sapilak BJ. Otępienie i depresja u pacjentów w podeszłym wieku w Praktyce Lekarza Rodzinnego. Fam Med Primary Care Rev. 2012;14,3:349-53.

28. Milanović Z, Pantelić S, Trajković N, Sporiš G, Kostić R, James N. Age-related decrease in physical activity and functional fitness among elderly men and women. Clin Interv Aging. 2013;8:549-56.

29. Andre N, Ferrand C, Albinet C, Audiffren M. Cognitive Strategies and Physical Activity in Older Adults: A Discriminant Analysis. J Aging Res. 2018; ID 8917535.

30. Tomioka K, Iwamoto J, Saeki K, Okamoto N. Reliability and Validity of the International Physical Activity Questionnaire (IPAQ) in Elderly Adults: The Fujiwara-kyo Study. J Epidemiol. 2011;21(6):459-65.

31. Skotnicka M, Pieszko M. Aktywność fizyczna receptą na długowieczność. Med Og Nauk Zdr. 2014;20(4):379-83.

32. Puciato D, Rozpara M, Mynarski W, Łoś A, Królikowska B. Aktywność fizyczna dorosłych mieszkańców Katowic a wybrane uwarunkowania zawodowe i społeczno-ekonomiczne. Med Pr. 2013;64(5):649-57.

33. Burton NW, Turrell G. Occupation, hours worked, and leisure-time physical activity. Prev Med. 2000;31(6):673-81.

34. Hwang A, Zhan YR, Lee WJ, Peng LN, Chen LY, Lin MH, et al. Higher Daily Physical Activities Continue to Preserve Muscle Strength After Mid-Life, But Not Muscle Mass After Age of 75. Medicine (Baltimore). 2016;95(22).

35. Albuquerquea APA, F. Borges-Silva F, Gomes da Silva Borges E, Pinto Pereira A, Dantas EHM. Physical activity: Relationship to quality of life and memory in older people. Sci Sports. 2017;32:259-65.

36. Leung P-M, Ejupi A, van Schooten KS, Aziz O, Feldman F, Mackey DC, et al. Association between Sedentary Behaviour and Physical, Cognitive, and Psychosocial Status among Older Adults in Assisted Living. Biomed Res Int. 2017; ID 9160504.

37. Reichert CL, Diogo CL, Vieira JL, Dalacorte RR. Atividade física e sintomas depressivos em idosos sul-brasileiros da comunidade. Rev Bras Psiquiatr. 2011;33(2):165-70. 